\title{
Effects of Human Disturbance on Terrestrial Apex Predators
}

\author{
Andrés Ordiz ${ }^{1,2, *} \mathbb{C}$, Malin Aronsson ${ }^{1,3}$, Jens Persson ${ }^{1} \mathbb{C}$, Ole-Gunnar Støen ${ }^{4}$, Jon E. Swenson ${ }^{2}$ and \\ Jonas Kindberg 4,5
}

Citation: Ordiz, A.; Aronsson, M.; Persson, J.; Støen, O.-G.; Swenson, J.E.; Kindberg, J. Effects of Human Disturbance on Terrestrial Apex Predators. Diversity 2021, 13, 68. https://doi.org/10.3390/d13020068

Academic Editors: Michael Wink and David Murrell

Received: 25 December 2020

Accepted: 7 February 2021

Published: 9 February 2021

Publisher's Note: MDPI stays neutral with regard to jurisdictional claims in published maps and institutional affiliations.

Copyright: (C) 2021 by the authors. Licensee MDPI, Basel, Switzerland. This article is an open access article distributed under the terms and conditions of the Creative Commons Attribution (CC BY) license (https:/ / creativecommons.org/licenses/by/ $4.0 /)$.
1 Grimsö Wildlife Research Station, Department of Ecology, Swedish University of Agricultural Sciences, SE-730 91 Riddarhyttan, Sweden; malin.aronsson@slu.se (M.A.); Jens.Persson@slu.se (J.P.)

2 Faculty of Environmental Sciences and Natural Resource Management, Norwegian University of Life Sciences, Postbox 5003, NO-1432 Ås, Norway; jon.swenson@nmbu.no

3 Department of Zoology, Stockholm University, SE-10691 Stockholm, Sweden

4 Norwegian Institute for Nature Research, NO-7485 Trondheim, Norway; ole.stoen@nina.no (O.-G.S.); jonas.kindberg@rovdata.no (J.K.)

5 Department of Wildlife, Fish, and Environmental Studies, Swedish University of Agricultural Sciences, SE-901 83 Umeå, Sweden

* Correspondence: andres.ordiz@gmail.com

\begin{abstract}
The effects of human disturbance spread over virtually all ecosystems and ecological communities on Earth. In this review, we focus on the effects of human disturbance on terrestrial apex predators. We summarize their ecological role in nature and how they respond to different sources of human disturbance. Apex predators control their prey and smaller predators numerically and via behavioral changes to avoid predation risk, which in turn can affect lower trophic levels. Crucially, reducing population numbers and triggering behavioral responses are also the effects that human disturbance causes to apex predators, which may in turn influence their ecological role. Some populations continue to be at the brink of extinction, but others are partially recovering former ranges, via natural recolonization and through reintroductions. Carnivore recovery is both good news for conservation and a challenge for management, particularly when recovery occurs in humandominated landscapes. Therefore, we conclude by discussing several management considerations that, adapted to local contexts, may favor the recovery of apex predator populations and their ecological functions in nature.
\end{abstract}

Keywords: carnivore recovery; ecological function; human disturbance; human-dominated landscapes; large carnivores; Northern hemisphere

\section{Introduction}

Humans and our activities have transformed planet Earth to the extent that no ecosystem is free of human influence [1], both in aquatic [2] and terrestrial realms [3]. The accumulation of alterations of ecological communities and ecosystem services poses threats to the survival of multiple species, including humans [4]. Here, we focus on terrestrial apex predators, i.e., large carnivores at the top of trophic chains, typically characterized by large body size, low densities, and large home ranges, whose abundance is usually not determined by other predators, but by factors like food availability [5]. The historical persecution of apex predators by humans has caused a loss and change of biodiversity in ecosystems, which in turn has revealed and highlighted the role of these species in nature [6-8].

Many terrestrial carnivores are declining globally, with pervasive consequences for ecosystems $[9,10]$. Most large carnivore mortality is caused by humans, even in protected areas $[11,12]$; thus, demographic studies have traditionally dominated the large-carnivore literature, aiming to reduce extinction risk and to favor long-term population viability $[13,14]$. Although many species continue to be at the brink of extinction [9], recently, we are witnessing the return of some large carnivore populations to their former ranges. This process 
is particularly remarkable in human-dominated landscapes of Europe [15] and North America [16], but efforts to protect large carnivores and their habitats have taken place in most continents [17], and improvements are visible in different places. For instance, the population of Amur tigers (Panthera tigris altaica) along the China-Russian border has gradually been increasing and extending its distribution into China since the late 1990s [18].

From a conservation perspective, the return of large carnivores is good news, but it also comes with several challenges, including potential threats, real or perceived, to human lives [19] and conflict with human activities [20,21]. This situation requires improved methods for population monitoring and forecasting to ease conservation and management $[22,23]$. Human-caused mortality continues to be the main driver of large carnivore demography, a pattern that holds for different species and on different continents [24-26], but recent research also focuses increasing attention to the behavioral responses of large carnivores to humans and our activities, building upon a body of research on human disturbance on other wildlife [27-29]. Regarding ecosystem services, the partial and ongoing large carnivore recovery in human-dominated landscapes does not necessarily mean that these species play the inherent ecological function of apex predators. Gray wolves (Canis lupus); bears (Ursus spp.); several felids, such as jaguars (Panthera onca), tigers (Panthera tigris), lions (Panthera leo), cougars (Puma concolor), and lynx (Lynx spp.); and a large mustelid, the wolverine (Gulo gulo), are large carnivore species that occupy the uppermost ladders of trophic systems in different ecosystems (i.e., what species is the apex predator in a given ecosystem is context dependent), but behavioral and demographic costs of both direct and indirect intervention by humans (e.g., hunting and displacement due to disturbance) may limit their ecological function [5].

In this review, we summarize (a) the ecological role that large carnivores can play in nature, (b) research on large carnivore responses to human disturbance, and (c) how the responses of large carnivore communities to human disturbance may influence their ecological function. We review how human activities cause spatial-temporal displacement of carnivores, which in turn modifies (typically reducing, but sometimes even reinforcing) the carnivores' role in some ecosystems. We conclude by suggesting management considerations based on this review.

\section{Apex Predator Function in Ecosystems}

In ecology, a long-term debate has focused on the processes that regulate ecosystems, with alternatives proposing a preponderance of bottom-up processes (limited by productivity), top-down processes (mediated by predation), or a combination of both, in addition to the influence of biotic and abiotic factors. Earlier work in the 1920s and 1940s inspired the first ideas highlighting the top-down effect of predators on herbivores and the increase of ungulate populations when predators were eradicated, which in turn influenced the vegetation [30]. Nevertheless, bottom-up processes are crucial and the relative role of different forces is context dependent, with top-down control from predators, interspecific interactions, and disturbance from natural and anthropogenic factors affecting population dynamics that are largely dependent on productivity [31-33]. In other words, both top-down and bottom-up processes function simultaneously in food webs, and human disturbance plays an increasingly major role in many ecosystems [34].

Regarding top-down effects exerted by apex predators, a key concept is "trophic cascades", i.e., the progression of effects caused by predators across successively lower trophic levels [6]. Predators can provide top-down control of community structure, a keystone ecological role that is a rationale for carnivore conservation [35]. Via predation, apex predators can control both their prey and mesopredators, both numerically and through nonlethal, behavioral effects [36-39]. Predation causes mortality, and predation risk and disturbance potentially affect population dynamics indirectly by forcing individuals to trade-off antipredator behavior (vigilance) and profitable activities (e.g., foraging and resting $[27,40])$. Furthermore, predators can play a significant role in the distribution of nutrients across landscapes, e.g., after consumption of prey and other indirect effects [41]. 


\subsection{Of Wolves and Bears, and beyond-Examples of Apex Predator Effects in Nature}

Historically, apex predators have been considered to be threats to livestock, game species, and people, and the lethal control of predators has been a management tool institutionalized by many governmental agencies [42]. Today, however, human perceptions also recognize intrinsic values in these species and their role in nature [43]. One example of these changing perceptions comes from Yellowstone National Park (USA), where the government eliminated wolves in the 1920s, just to reintroduce them in the 1990s [43]. This case provided a remarkable example of the effects of losing predators in nature, to the extent that "the reintroduction of gray wolves to Yellowstone National Park is the most celebrated ecological experiment in history" [44]. Research carried out in this ecosystem in the last two decades explores, among other things, the relative impact of predation in terms of numerical and behaviorally mediated effects on both mesopredators and prey [44-50], which is further complicated by the modulating effects of climatic factors [33,51].

Beyond the debate on the relative importance of numerical and behavioral effects of predation, and the warning that effects of wolf recovery in Yellowstone will take decades to unfold [52], the reintroduced wolf population has caused spatial and temporal variability in predator-ungulate interactions that reflect on lower levels via trophic cascades (summarized in [44]). Crucially, increasing predation by brown bears (Ursus arctos) and cougars and increasing numbers of alternative prey are turning what was a simpler prey (elk; Cervus canadensis) - predator (wolf) interaction into a more complex system [44]. This highlights the role of predation as an ecological function of complete large carnivore guilds, as shown elsewhere [53].

A longer-term perspective on the effects of predator-prey interactions and cascading effects on vegetation is available from Isle Royale, Lake Superior (USA), where wolves returned naturally more than 50 years ago. Initially, the system was interpreted as a top-down process driven by wolf predation [54]. Later, the role of both top-down and bottom-up processes received more support [55], and Vucetich and Peterson [56] assessed that interannual variation in moose (Alces alces) population growth rate was affected by naturally occurring fluctuations in wolf abundance. Wolf predation has been a major mortality cause for Isle Royale moose, and both top-down and bottom-up processes are involved, but abiotic factors explain inter-annual variation of moose numbers $[51,56]$. Despite using 40 years of data, the best models barely explained approximately half of the variation in moose population growth rate in the case of Isle Royale [56], which illustrates the complexity of regulatory processes that involve multiple factors.

Overall, predation plays an important role in the above mentioned North American ecosystems, yet bottom-up processes and especially abiotic factors, such as climate, are main drivers of variation in prey population dynamics [56]. Climate can drive predation to be more or less additive from year to year [33] and may determine where predation affects prey the most, e.g., depending on snow depth $[57,58]$. Nevertheless, evidence on trophic cascades driven by apex predators comes today from an increasing number of study areas and involving different prey and plant communities, as well as reflects on a wide variety of ecosystem characteristics [35,59-62].

Besides gray wolves, brown bears are the large carnivore with the widest distribution in the Northern Hemisphere [63]. As large carnivores in general, the brown bear is threatened by human-caused mortality, habitat fragmentation, and habitat loss [64]. Brown bears and other bear species are efficient predators of ungulates, especially calves [65,66]. As omnivores, bears also eat insects, fish, and plants, i.e., a diverse foraging behavior linked to several ecological effects. For instance, predation on Pacific salmon (Oncorhynchus spp.) by North American bears may have shaped some of the salmon's traits, causing divergence in the senescence, size, and shape of salmon in different populations, depending on predation risk [67]. This example of predator-prey interaction has been used to illustrate the role of predation as a driver of natural selection and evolution [68]. Furthermore, bears contribute to transfer nitrogen from oceanic to terrestrial systems through predation on spawning salmon, i.e., bears are a strongly interactive species involved in ecosystem effectiveness [7]. 
Ants, as a bear food, provide another example. Ants are ecosystem engineers, whose effects in nature manifest through multiple paths and interactions with other organisms and ants are a very important food for a large variety of wildlife, including bears $[69,70]$. For instance, ants provide $\sim 20 \%$ of the total annual digestible energy of Scandinavian brown bears [71], and bear foraging on ants has, in turn, indirect consequences for lower trophic levels. For example, predation on ants by American black bears (Ursus americanus) reduced the protection that ants provide to herbivorous insects through a mutualistic relationship, allowing arthropod predators to suppress the herbivores, which benefited plants [72]. Grinath [73] followed up this line of research and suggested that conservation of bears and other omnivores and predators that generate trophic cascades may be essential for managing the long-term effects of nitrogen deposition in ecosystems caused by human activities.

Besides the role of bear predation on ungulates, fish, and ants, bears are particularly important seed dispersers, which may influence plant community composition [74]. Brown bears can play a key role in dispersing seeds between habitats and can indirectly provide a nutritional subsidy to small mammal populations via deposition of seed-rich bear scats across landscapes [75]. Seed dispersion after ingestion by brown bears stimulates seed germination [76], and the role of bears as seed dispersers has been indeed highlighted in different continents $[77,78]$.

The role of different bear species as seed dispersers may not be that surprising because bears are omnivores, but that capacity is not limited to bears. Cougars, one of the largest and most widely ranging apex felid predators, characterized by a strictly carnivorous diet, also seem to be an effective seed disperser, establishing direct and nonherbivore mediated interactions with plants. Cougars ingest and spread thousands of seeds of plants initially consumed by their ungulate prey, i.e., obligate carnivores can also display overlooked ecological functions [79].

Interactive effects of apex predators in ecosystems also include intraguild interactions, the distribution of prey carcasses in the landscape, and resulting heterogeneity in soil nutrients, which in turn can influence community biodiversity [80]. As scavengers of their own and other predators' kills, predators also play an important function in nature. Scavenging accelerates the return of nutrients to trophic webs, disseminates nutrients, and helps dilute potentially infective spots [81]. For instance, wolverines, the largest terrestrial mustelid, have a circumpolar, Holarctic distribution across alpine, tundra, and northern taiga habitats, where they play an important role as both predators and scavengers [82]. Bears, wolves, lynx, and wolverines, the sympatric large carnivore guild in wide areas at boreal latitudes $[83,84]$, select habitats differently [85], thus playing complementary roles, which gives stability to ecosystem processes [7].

Synthesis: Although the effects of many apex predators in ecosystems are well documented, many more remain to be discovered. In short, most effects occur through the depletion and fear-induced behavior of their prey, which can have direct and indirect consequences at lower trophic levels [86].

\section{Effects of Human Activities on Large Carnivore Behavior}

Apex predators are rare and their abundance is not controlled by other predators; thus, they have, in an evolutionary perspective, fewer antipredator adaptations than subordinate guild members and prey species [87]. They have large home ranges, which increases their chances of encountering humans, our activities, and human-related features as barriers in the landscape $[26,88]$. Inhabiting landscapes where human-caused mortality is the main threat for apex predators triggers behavioral responses that resemble those of prey [89]. Such responses need to be considered to explain the present density, distribution, and behavior of large carnivores [90], and also to ensure their conservation [91].

In recent times, research based on fine-scale empirical data (e.g., tracking GPS-collared animals and camera traps) shows that large carnivores facing human activities adjust their habitat use and daily activity patterns, trading off vigilance and other activities, i.e., 
carnivores show spatial and temporal reactions to avoid humans and our activities. Spatial and temporal reactions to human activities have been documented in Scandinavia, for instance, where carnivore mortality is, as elsewhere, mostly caused by humans [24,92,93]. Spatially, carnivores select habitats to avoid humans, especially during daytime [94], as supported by studies at different orders of habitat selection $[95,96]$. At a very fine scale, carnivores select resting sites and natal den sites by seeking denser cover and more rugged terrain the closer they are to human settlements $[89,97]$. Bears and wolves run away and move to even more concealed spots after encounters with people in the forest [98-100]. The distribution of Eurasian lynx (Lynx lynx) in the landscape is a trade-off between food availability and human activity because the density of their main prey (roe deer Capreolus capreolus) is higher in agricultural landscapes, where human activity is also high [101].

Temporally, bears become more nocturnal when hunting seasons start [102], where road density (a proxy of human disturbance) is higher [103,104], and after encountering people [105], a pattern that holds, without sign of habituation to human presence, after repeated experimental encounters [106]. Combining GPS and heart rate loggers showed that the highest bear stress levels occur when bears are near villages [107]. Likewise, physiological costs associated to fear responses to anthropogenic threats have also been shown in other marine and terrestrial predators [108].

Spatial avoidance of human disturbance is indeed a major driver of carnivore habitat selection and use at different spatial scales and for multiple species [109-113], which ultimately reflects on demography. For instance, tiger and brown bear abundance is higher in areas with lower disturbance levels than in more disturbed places $[114,115]$. Temporal avoidance of human activities leads to increased nocturnality of wildlife (including large carnivores), which may favor coexistence with mostly diurnal humans, but also implies fitness (and other) costs [116]. Long-term, human-caused selection likely explains the crepuscular-nocturnal behavior of large carnivores, compared to areas with a shorter history of persecution $[89,117]$. Long-term human pressure also is reflected in demography, e.g., bears have higher reproductive rates in areas with longer-term persecution [118]. Recreational human activities, not only lethal and commercial activities, that change landscapes (forestry, roads, urbanization) also cause spatio-temporal displacement of large carnivores [119-122].

Synthesis: Habitat loss and historical human persecution have caused a demographic decline of large carnivores at a worldwide scale [9]. In addition, humans as "superpredators" [123] trigger behavioral responses by carnivores that resemble those of prey and that occur at both spatial and temporal scales, constraining their habitat use and daily activity patterns [5].

\section{Behavioral Responses of Large Carnivores to Human Disturbance May Alter Their Ecological Role}

As summarized above (Section 2.1), direct mortality of and fear-induced behavior in prey cause most of the effects that apex predators play in nature. Crucially, these are the same effects that human disturbance cause on large carnivores, and this may in turn influence their ecological role. Reduced carnivore populations are less able to control their prey numerically, and spatio-temporal behavioral responses of carnivores to avoid humans may limit their capacity to cause behavioral-mediated effects on prey [5].

From a numerical perspective, large carnivore removal may cause mesopredator and herbivore release, leading to biodiversity loss, a process documented in different ecosystems [124-127]. From a behavioral perspective, the spatial and temporal responses of large carnivores to human disturbance are also evident at lower trophic levels, e.g., spatial avoidance of humans by large carnivores creates human shields or refugia for prey [35,128-130]. In turn, prey redistribution may change landscape characteristics and habitat availability and use of other species [59]. Spatial separation of predators and humans can facilitate their coexistence, but it also triggers pervasive effects, altering natural interactions, e.g., overabundant herbivores occur in areas where they are released from predation risk [5]. 
Temporal avoidance of humans may facilitate human-wildlife coexistence, as well, but it also alters community interactions, beyond disrupting diel patterns of activity of affected species [116]. Wildlife behavioral reactions to human disturbance are now receiving more attention, but many ecological consequences of those responses remain mostly uninvestigated [116,131,132].

Regarding large carnivores, more nocturnal behavior in human-dominated landscapes facilitates mesopredator release during daytime [133]. Predator nocturnal behavior can also create temporal human shields for prey, which may move closer to human-dominated areas at night to escape predation [116]. However, predator kill rates are not necessarily lower in human-encroached areas. Fidelity to kill sites and consumption of prey decline in disturbed areas for cougars, for instance, leading to increased kill rates and potential additional effects on other species, via the provision of more scavenging opportunities $[134,135]$. Wolverines linger less time at baited sites in disturbed areas, a behavioral response that, extrapolated at the landscape scale and in the long term, may negatively influence population trends in disturbed areas [136]. Therefore, the reactions of different carnivores to humans in humandominated areas vary, which requires further research to draw appropriate conclusions for different species and in different ecosystems.

Spatial avoidance of human settlements and other human features of the landscape can also influence the role of large carnivores in nature. As described above (Section 2.1), bears forage largely on ants, and bears show multiple antipredator responses to humans (Section 3). Via predation and disturbance of anthills, bears reduce the abundance of ants, but bear avoidance of humans limits that effect. In Scandinavia, the anthills of keystone ant species eaten by bears are larger closer to human settlements, which bears avoid; thus, humans mediate cascading effects in the boreal forest by altering interactions among bears and ants, indirectly affecting other species [137]. Research unrevealing more effects of predators in ecosystems suggests that changes in predator communities may have cascading consequences that facilitate the emergence of zoonotic diseases. For instance, a connection between wolf extirpation, which led to a coyote (Canis latrans) expansion that caused a red fox (Vulpes vulpes) decline that ultimately favored abundance of small mammals, may help explain the incidence of Lyme disease, i.e., changes in predator communities may trigger down in trophic cascades and reflect on many ecological issues, including human health [138]. In Eurasia, African swine fever has spread dramatically over the last decade, affecting wild boar (Sus scrofa) and domestic pigs and causing a very high economic impact [139]. Where this fever is diagnosed, a reduction of the wild boar population is recommended to stop its spread, but management of wild boars via hunting in Europe seems to be difficult and wolves have not yet returned to many areas where wild boars thrive [140]. Where wolves prey on wild boar, they target mainly piglets and young individuals [141,142], which may not have per se a strong effect on the population regulation of wild boars, but natural predation adds to hunting effects and informs hunting models that aim to reduce the size of wild boar populations [140].

Effects of human disturbance on predator-prey interactions are also related to the introduction of exotic species in ecosystems. In South America, the introduction of exotic prey species (e.g., European hares Lepus spp.) may have caused an increase in abundance of native carnivores, such as cougars, reinforcing a top-down effect on native prey, a process that has likely occurred elsewhere and involving different species assemblages [143]. In Australia, lethal control of dingo (Canis lupus dingo) has favored the spread of exotic species, such as foxes and cats, which in turn has caused huge biodiversity losses [144].

Habitat alteration by human activities can also increase prey density, favoring predators that then exert increased predation pressure on endangered prey. In North America, this seems to be the case involving forestry, which favored an increase in moose densities that was followed by increased wolf predation on ungulates, including endangered caribou (Rangifer tarandus) populations ([145] and references therein). In addition, predator access to anthropogenic food, including livestock and other food items, causes behavioral and/or increased predator abundance and alters trophic cascades [146]. In Italy, for instance, where 
wolves have recovered in recent decades [147], large amounts of available livestock carrion strongly depress predatory behavior of wolves, despite the occurrence of abundant wild prey, which in turn reduces potential top-down cascading effects of wolf predation [142]. Wolf recovery in Italy and other countries has also brought attention to the issue of hybridization between wolves and domestic dogs, which is likely more common following wolf recovery in human-dominated landscapes, where dog populations are larger [147,148].

In an increasingly human-dominated world that challenges wildlife in general and large carnivores in particular [123], a question is whether it is possible to expect that apex predators play their nominal role widely or if that is context dependent. Cases like the wolf recovery in Yellowstone, which, in addition to bear and cougar predation, has generated trophic cascades at lower trophic levels, exist, but caution is needed when extrapolating results to areas with larger human intervention [44]. In Europe, for instance, where most landscapes are heavily impacted by human activities, it might be more difficult to expect that remnant and recolonizing populations of large carnivores fully develop apex predator roles. Kuijper et al. [149] suggested that the potential for density-mediated trophic cascades in human-dominated landscapes is limited to unproductive areas, where even low carnivore numbers may impact prey densities, or where carnivores are allowed to reach ecologically functional densities. Kuijper et al. [149] suggested that the potential for behavioral-mediated trophic cascades may be larger because even low carnivore densities may affect prey behavior. Predator-prey interactions in anthropogenic landscapes will be highly context dependent, and human influence will often attenuate the ecological effects of large carnivores [149]. Likewise, in North American human-dominated areas, human influence may favor bottom-up predominance and weaken top-down trophic cascades, and human impact through multiple paths may override other top-down and bottom-up effects [34].

Intermediate situations also exist and illustrate that processes of ecosystem regulation vary largely in areas that are close to each other, depending on the degree of human pressure or impact. For instance, recolonization of wolves in Banff National Park (Canada) reduced prey density and indirectly influenced vegetation and other trophic levels, in a trophic cascade fashion, but wolf exclusion in urban areas disrupts these effects [35]. This illustrates that human exclusion of wolves and other predators may affect ecosystems, supporting conservation and management based on the trophic importance of large carnivores in terrestrial systems [35].

A message arising from the Yellowstone and Banff cases is that protected areas are ecological baselines that allow evaluating how humans affect nature [44]. In those systems, wolves reached ecologically efficient or functional densities that triggered trophic cascades, whereas carnivore recovery in some European areas may not have reached that level yet and/or ecosystems have been too severely transformed for apex predators' return to have an impact. In Sweden, for instance, wolf recovery, which started in the early 1990s [84], may not yet have changed the behavior of its staple prey, moose [150]. However, wolf presence in Finland, where wolves were never eradicated, alters moose behavior [151]; wolf and lynx recovery in Scandinavia may have benefited the wolverine by increasing carcass availability [83,152]; and wolves and lynx suppress red foxes in Fennoscandia, although fox population trends are also affected by other factors [153,154].

Jedrzejewska and Jedrzejewski [155] studied predator (wolf and lynx)-ungulate (including European bison (Bison bonasus), moose, wild boar, red deer (Cervus elaphus), and roe deer interactions in the temperate forest of Bialowieza National Park (Poland). Wolf and lynx predation kept red deer and roe deer below carrying capacity and constantly provided remains for scavengers, whereas larger-bodied prey (bison and moose) and wild boars seemed to be limited by resources, i.e., both top-down and bottom-up effects were involved in regulating the population dynamics of ungulates [155]. In the rich predatorprey assemblage of Serengeti National Park (Tanzania), smaller prey species experienced larger effects from predation than larger ones, which rather were limited by food [31]. Besides providing further evidence of the combined nature of regulatory processes in 
nature, which is most likely the norm in many ecosystems [34], the study of Jedrzejewska and Jedrzejewski [155] illustrates carnivores' ecological function in European landscapes, highlighting again the role of protected areas. Nevertheless, it is worth noticing that also carnivores living in multiple use landscapes and themselves facing severe conservation threats can control mesopredator populations, which further affects prey abundance. For instance, Iberian lynx (Lynx pardinus) favor densities of their own staple prey, rabbits (Oryctolagus cuniculus), by killing and reducing densities of smaller predators [156].

Synthesis: Predators that trigger varying effects on lower trophic levels occur in a wide variety of ecosystems, yet the amplitude of those effects is dependent on many factors that are not only related to the predators, but to human activities that affect all trophic levels, from top predators to ecosystem productivity, potentially altering both top-down and bottom-up regulatory processes [35,130,131,150]. Where carnivores are recolonizing former ranges, they likely need (a) to reach ecologically functional densities [7] and (b) time to trigger visible effects on lower trophic levels because ecological responses generally require long times to occur [131]. Furthermore, in human-dominated landscapes with fragmented habitats and recolonizing carnivores, predator-prey interactions may also develop in novel directions that are yet to be documented [157].

\section{What Next?}

Top-down control by predators, bottom-up regulation by environmental productivity, variation induced by climate, and human impact are involved in the regulation of ecosystems and growth rates of populations [32-34,51,125,158]. Accumulating evidence supports that apex predators play keystone roles in many ecosystems [8,9], with mechanisms driving their function continuously revealed by new findings [62,132] and many more remaining to be shown $[86,131]$.

Human-large carnivore relationships have often focused on conflict, with little attention to ecosystem services [159]. Predator control was widely accepted by the general public, but has since become a source of social conflict $[42,43]$, and interest in non-lethal management alternatives is increasing [160]. Many large carnivore populations continue to be severely threatened $[9,161,162]$, whereas some are recovering former ranges [15]. Demographic issues, thus, remain crucial to favor long-term population viability, but behavioral responses of large carnivores and other wildlife can also influence their fitness [116,163-167]. Apex predators are highly interactive species [7], and both demographic and behavioral responses to human persecution and human activities may limit their ecological role. Thus, the conservation and management of large carnivores should also consider, together with demographic issues, their behavioral responses [5,168].

Human impacts affect ecosystem functions in multiple ways, and understanding how growing human impact is propagated through food webs is a challenge [34]. Among other issues, human impact changes animal behavior, and, although all species inherently interact with others, the behavior of keystone species is particularly critical for ecosystem function [131]. Eliminating human disturbance may be impossible in most ecosystems, leaving managers with options to restrict certain activities, based on expected implications for animal behavior and ecosystem function [131]. Large carnivore demography and behavior are affected by management decisions that are often influenced by human-wildlife conflicts [43,169]. All of these factors highlight that management and conservation goals for apex predators are dependent on social-ecological trade-offs, e.g., more ambitious recovery goals, aiming at the restoration of carnivores and ecological interactions with other species, may be more feasible in large protected areas than where conflict levels are high [170].

Protecting large connected areas for large carnivore conservation has been one of the main tools suggested for rewilding ecosystems, a highly debated proposal to counteract biodiversity loss on Earth [171]. Whereas carnivore recolonization and reintroductions in ecosystems where they have been eradicated long ago and their legal protection by international and national laws are often controversial, as illustrated for instance by the natural arrival of wolves to the Alps [172] and the reintroduction of bears in the Pyrenees [173], 
the expansion of large carnivore populations gives a chance to recover apex predators' role in nature. However, large carnivore recovery and maintenance of ecological interactions in human-dominated landscapes is a challenging task, and some management actions may make it more feasible.

\section{Management Considerations}

Conserving carnivore populations and favoring their ecosystem function require careful attention by management agencies. The following considerations should probably be considered everywhere, whereas the feasibility and specific implementation (or not) will have to be adjusted to different ecosystems and social contexts.

(1). Connectivity. Favoring connectivity with wilderness and protected areas helps secure persistence of large carnivores in human-dominated areas. Different carnivore populations have been recovering in human-dominated landscapes, showing that landsharing strategies may work [15], whereas their long-term persistence may also depend on connectivity with and between protected areas $[167,174]$. This will facilitate aims to preserve not only mere coexistence but also the ecological role of large carnivores in ecosystems [146].

(2). Spatial separation. Designation of areas with prioritized goals, e.g., via zoning of specific areas for different purposes, may prevent conflict and favor carnivore conservation. Research showing the distance at which humans influence carnivore behavior $[107,175]$ can guide zoning to help separate human settlements and property (e.g., livestock), so that behavioral adjustments made by carnivores in response to people are minimized, and people's capacity to protect their property from carnivores is maximized [90]. Besides reducing conflict $[104,176]$, spatial separation between human activities and carnivores would ease the occurrence of ecological interactions. In some areas, zoning seems crucial to maintain threatened populations [114]. In other areas, alternative measures may be more feasible, such as compensation systems of depredation, which are used for example in northern Scandinavia (and in many other places in Europe), where large carnivores largely rely on privately own, free-ranging reindeer (Rangifer tarandus) [177].

Different management actions could be used to promote spatial separation. For instance, Naha et al. [178] suggested removing vegetation cover around human settlements to reduce depredation, whereas thick vegetation cover is essential elsewhere to provide concealment to carnivores [89]. Area-based conservation efforts have varying goals and being successful implies collaborating with local communities and stakeholders [179], i.e., management actions will have to be adjusted for different goals and at different spatial scales. Limiting road construction, reducing road density and/or their use, and closing roads seasonally or permanently after they have served their purpose is another example of management options to reduce disturbance and retain habitat quality for large carnivores [103,113].

(3). Temporal separation. Management options could include "temporal zoning" [116], an approach analogous to spatial zoning, to limit human activities during times of the day and/or seasons when interactions are most disturbing. Designing landscapes of coexistence should aim at facilitating both the spatial and temporal segregation of human structures and activities and large carnivores, preventing new sources of disturbance in their most important habitats and phenological periods, e.g., at breeding sites [180].

(4). Recreation. In some areas, there is a need for the regulation of recreational activities, including those that target direct observation of carnivores and those that use carnivore habitats for other motorized and nonmotorized recreational activities. Recreation can cause temporal and spatial displacement of large carnivores, which entails energetic and behavioral costs $[120,121,181]$. Quantifying spatial and temporal displacement of animals by human recreation can help guide management strategies to mitigate impacts, e.g., to enforce off-trail regulations and to establish temporal limitations for specific activities [119]. In some places, restriction of public presence may help poachers go undetected, which may explain for instance why illegal killing of lynx, wolverines, and bears was higher in 
three large national parks than in surrounding unprotected areas in northern Sweden [12]. In many other areas, however, tourism and recreation can both have negative ecological impacts on habitats and species, including carnivores $[182,183]$. Altogether, it is necessary to monitor and regulate such activities to promote their positive effects and prevent the negative ones [121].

(5). Anthropogenic foods. Reduce access of large carnivores to anthropogenic foods (e.g., garbage, livestock, beehives). Reducing predator access to such food sources is important to prevent habituation to humans and minimize carnivore mortality [165], to reduce human-carnivore conflicts, and to preserve ecosystem functioning [142,146]. Large carnivore interactions with people and our property leads to conflict, which complicates management and can jeopardize conservation [20]. Minimizing the occurrence of damages is possible with a variety of tools, depending on the carnivore species and type of damage [184-187], yet it also requires proactive attitudes by key stakeholders and management agencies and the implementation of efficient measures [188]. Minimizing damages will reduce conflict, which in turn should ease reaching ecologically efficient densities of large carnivores. For example, the accessibility to free-ranging livestock is a key factor favoring wolf attacks in Spain, regardless of the abundance of wild prey; thus, efficient protection of livestock is needed if extensive grazing continues to be promoted by European Union's Common Agricultural Policy (CAP) [189]. Otherwise, subsidized high densities of unprotected livestock are fueling conflict and potentially altering interactions between natural prey and predators, the densities of which can also increase, as discussed above (Section 4).

(6). Lethal control. Regulated carnivore hunting is a common management option used to reduce conflict and that can generate revenue for conservation, but it can have indirect effects, e.g., it may not necessarily reduce poaching [190], can drive carnivore population declines if the harvest is too high [10] and, in the long term, hunting can reshape the life history of apex predators [191]. From a behavioral perspective, hunting is one of the human activities that triggers the clearest responses in large carnivores $[89,102]$ and challenges their function as apex predators [5,123], although it could have desired effects by keeping carnivores away from humans and human property. Van Eeden et al. [184] conducted a worldwide meta-analysis of research on conflict mitigation related to large carnivores and humans, focusing on conflicts caused by large carnivores, such as livestock depredation. They concluded that nonlethal management options (e.g., guardian dogs) can be as effective as lethal control of carnivores [184]. Success of lethal control to reduce damages varies considerably among different places and evidence is accumulating in different continents showing that lethal control of social carnivores can sometimes increase livestock losses [20,184]. Hunting displaces carnivores and disrupts their social structure, which are likely some of the mechanisms explaining increased depredation after lethal control [190,192]. Mesopredator release and increased ungulate numbers across Europe and North America are also consequences of eradicating apex predators $[43,138]$. Predator control to conserve threatened prey, for instance, may need to be applied forever, unless conservation aims at restoring whole ecosystem functioning [43]. Because of the above reasons, minimizing hunting of large carnivores to favor their ecological function has been suggested earlier [5]. Where lethal control is implemented, it is important to monitor and understand the reciprocal effect between the control as a management action and the behavioral and demographic response of the targeted carnivores. Such reciprocal effects should inform the implementation of the management action for it to be efficient, e.g., to actually reduce depredation while causing the lowest harm to carnivore conservation.

(7). Ecological interactions. Research in, for instance, Yellowstone National Park has shown that predation is not a function of a single species, but that the joint effect of wolf, bear, and cougar predation triggered effects that rippled down through lower trophic levels (Section 2.1). Likewise, research in Africa has shown that conserving complete carnivore guilds is important for them to perform their ecological role [53]. Stability of ecological interactions in complete carnivore guilds is, thus, important to favor their ecological function. Wolf and Ripple [193] examined the spatial extent of complete large carnivore 
guilds at worldwide and regional scales and found that complete guilds occupy $34 \%$ of the world's terrestrial area, compared with $96 \%$ in historic times. Today, recovery of several overlapping species in some areas provides opportunities for the recovery of complete guilds and their interactions. That is the case for northern Eurasia, for instance, where wolves, bears, lynx, and wolverines have expanded in recent times $[9,15]$, favoring interspecific interactions $[65,194]$. Further research should document the effects that carnivore sympatry may trigger on lower trophic levels, including prey and other species, provided that recovery continues in the near future.

(8). Human dimensions. Lack of communication among research, conservation, and management, leading to research-implementation gaps, has been highlighted as a major environmental issue $[195,196]$. Carnivore conservation and management in humandominated landscapes illustrate the point. These are not only scientific issues because carnivore management and conflict resolution among involved stakeholders require social and political input to be successful $[169,197,198]$. Solid scientific evidence alone is not sufficient to manage predators effectively because social acceptability is equally important [43]. Implementation of the management considerations discussed above as actual management actions requires area-specific adjustments that consider the socio-ecological context, e.g., the carnivore species or guild present in an area and the human-carnivore conflict and/or sources of human disturbance. For instance, spatial or temporal separation between carnivores and humans and human property may be an option to reduce conflict and disturbance in some ecosystems, but not in others, and similar concerns apply to other potential actions. Management interventions can only be effective if they are actually implemented and used (e.g., to adjust ungulate harvest by hunters in ecosystems where large carnivores are recovering [199]), and acceptance by involved stakeholders is an important asset or requisite for that to occur [21].

In conclusion, evidence is accumulating that shows that apex predators can help restore ecosystems, although an increasing amount of research also shows multiple behavioral reactions of large carnivore communities to human disturbance. Overall, spatial and temporal separation between humans and our activities (professional and recreational) and property (livestock, beehives, etc.) and large carnivores reduces conflict and the pervasive effects of human disturbance on them. Reaching and maintaining ecologically efficient densities of large carnivores in human-dominated, disturbed areas is a key ecological and management task, and the ongoing natural recovery of several carnivores provides new opportunities and challenges to achieve it.

Author Contributions: Conceptualization, A.O.; resources, A.O., M.A., J.P.; writing-original draft preparation, A.O.; writing-review and editing, all authors; funding acquisition, J.E.S., J.K., O.-G.S., J.P., and M.A. All authors have read and agreed to the published version of the manuscript.

Funding: The Scandinavian bear and wolverine research projects have been funded by the Norwegian Environment Agency, Swedish Environmental Protection Agency, Norwegian Research Council, Austrian Science Fund, Norwegian Institute for Nature Research, Swedish Association for Hunting and Wildlife Management, Swedish Carnivore Association, WWF Sweden, Carl Tryggers Foundation, and Marie-Claire Cronstedt Foundation. The latter two also funded A.O. work on this manuscript. M.A. was funded by Formas grant 2015-826.

Conflicts of Interest: The authors declare no conflict of interest. The funders had no role in the design of the study, in the collection of literature or in the writing of the manuscript and its publication.

\section{References}

1. Vitousek, P.M.; Mooney, H.A.; Lubchenco, J.; Melillo, J.M. Human Domination of Earth's Ecosystems. Science 1997, 277, 494-499. [CrossRef]

2. Halpern, B.S.; Walbridge, S.; Selkoe, K.A.; Kappel, C.V.; Micheli, F.; D’Agrosa, C.; Bruno, J.F.; Casey, K.S.; Ebert, C.; Fox, H.E.; et al. A global map of human impact on marine ecosystems. Science 2008, 319, 948-952. [CrossRef]

3. Haberl, H.; Erb, K.H.; Krausmann, F.; Gaube, V.; Bondeau, A.; Plutzar, C.; Gingrich, S.; Lucht, W.; Fischer-Kowalski, M. Quantifying and mapping the human appropriation of net primary production in earth's terrestrial ecosystems. Proc. Natl. Acad. Sci. USA 2007, 104, 12942-12947. [CrossRef] 
4. Kremen, C.; Ostfeld, R.S. A Call to Ecologists: Measuring, Analyzing, and Managing Ecosystem Services. Front. Ecol. Environ. 2005, 3, 540. [CrossRef]

5. Ordiz, A.; Bischof, R.; Swenson, J.E. Saving large carnivores, but losing the apex predator? Biol. Conserv. 2013, 168, 128-133. [CrossRef]

6. Terborgh, J.; Estes, J.A. Trophic Cascades; Island Press: Washington, DC, USA, 2010.

7. Soulé, M.E.; Estes, J.A.; Miller, B.; Honnold, D.L. Strongly Interacting Species: Conservation Policy, Management, and Ethics. Bioscience 2005, 55, 168-176. [CrossRef]

8. $\quad$ Estes, J.A.; Terborgh, J.; Brashares, J.S.; Power, M.E.; Berger, J.; Bond, W.J.; Carpenter, S.R.; Essington, T.E.; Holt, R.D.; Jackson, J.B.C.; et al. Trophic Downgrading of Planet Earth. Science 2011, 333, 301-306. [CrossRef] [PubMed]

9. Ripple, W.J.; Smith, D.W.; Estes, J.A.; Beschta, R.L.; Wilmers, C.C.; Ritchie, E.G.; Hebblewhite, M.; Berger, J.; Elmhagen, B.; Letnic, M.; et al. Status and ecological effects of the world's largest carnivores. Science 2014, 343, 1241484. [CrossRef] [PubMed]

10. Creel, S.; Becker, M.; Christianson, D.; Droge, E.; Hammerschlag, N.; Hayward, M.W.; Karanth, U.; Loveridge, A.; Macdonald, D.W.; Matandiko, W.; et al. Questionable policy for large carnivore hunting. Science 2015, 350, 1473-1475. [CrossRef] [PubMed]

11. Woodroffe, R.; Ginsberg, J.R. Edge effects and the extinction of populations inside protected areas. Science 1998, 280, 10-13. [CrossRef]

12. Rauset, G.R.; Andrén, H.; Swenson, J.E.; Samelius, G.; Segerström, P.; Zedrosser, A.; Persson, J. National Parks in Northern Sweden as Refuges for Illegal Killing of Large Carnivores. Conserv. Lett. 2016, 9, 334-341. [CrossRef]

13. Purvis, A.; Gittleman, J.L.; Cowlishaw, G.; Mace, G.M. Predicting extinction risk in declining species. Proc. R. Soc. B Biol. Sci. 2000, 267, 1947-1952. [CrossRef] [PubMed]

14. Carroll, C.; Noss, R.F.; Paquet, P.C.; Schumaker, N.H. Use of population viability analysis and reserve selection algorithms in regional conservation plans. Ecol. Appl. 2003, 13, 1773-1789. [CrossRef]

15. Chapron, G.; Kaczensky, P.; Linnell, J.D.C.; Von Arx, M.; Huber, D.; Andrén, H.; López-Bao, J.V.; Adamec, M.; Álvares, F.; Anders, O.; et al. Recovery of large carnivores in Europe's modern human-dominated landscapes. Science 2014, 346, 1517-1519. [CrossRef] [PubMed]

16. Bruskotter, J.T.; Shelby, L.B. Human Dimensions of Large Carnivore Conservation and Management. Hum. Dimens. Wildl. 2010, 15, 311-314. [CrossRef]

17. Weber, W.; Rabinowitz, A. A global perspective on large carnivore conservation. Conserv. Biol. 1996, 10, 1046-1054. [CrossRef]

18. Wang, T.; Royle, A.J.; Smith, J.L.D.; Zou, L.; Lü, X.; Li, T.; Yang, H.; Li, Z.; Feng, R.; Bian, Y.; et al. Living on the edge: Opportunities for Amur tiger recovery in China. Biol. Conserv. 2018, 217, 269-279. [CrossRef]

19. Penteriani, V.; Delgado, M.D.M.; Pinchera, F.; Naves, J.; Fernández-Gil, A.; Kojola, I.; Härkönen, S.; Norberg, H.; Frank, J.; Fedriani, J.M.; et al. Human behaviour can trigger large carnivore attacks in developed countries. Sci. Rep. 2016, 6, 1-8. [CrossRef]

20. Fernández-Gil, A.; Naves, J.; Ordiz, A.; Quevedo, M.; Revilla, E.; Delibes, M. Conflict misleads large carnivore management and conservation: Brown bears and wolves in Spain. PLOS ONE 2016, 11, e0151541. [CrossRef]

21. Eklund, A.; Johansson, M.; Flykt, A.; Andrén, H.; Frank, J. Believed effect-A prerequisite but not a guarantee for acceptance of carnivore management interventions. Biol. Conserv. 2020, 241, 108251. [CrossRef]

22. Bischof, R.; Milleret, C.; Dupont, P.; Chipperfield, J.; Tourani, M.; Ordiz, A.; de Valpine, P.; Turek, D.; Royle, J.A.; Gimenez, O.; et al. Estimating and forecasting spatial population dynamics of apex predators using transnational genetic monitoring. Proc. Natl. Acad. Sci. USA 2020, 117, 30531-30538. [CrossRef]

23. Andrén, H.; Hobbs, N.T.; Aronsson, M.; Brøseth, H.; Chapron, G.; Linnell, J.D.C.; Odden, J.; Persson, J.; Nilsen, E.B. Harvest models of small populations of a large carnivore using Bayesian forecasting. Ecol. Appl. 2020, 30, e02063. [CrossRef] [PubMed]

24. Bischof, R.; Swenson, J.E.; Yoccoz, N.G.; Mysterud, A.; Gimenez, O. The magnitude and selectivity of natural and multiple anthropogenic mortality causes in hunted brown bears. J. Anim. Ecol. 2009, 78, 656-665. [CrossRef]

25. Heurich, M.; Schultze-Naumburg, J.; Piacenza, N.; Magg, N.; Červený, J.; Engleder, T.; Herdtfelder, M.; Sladova, M.; Kramer-Schadt, S. Illegal hunting as a major driver of the source-sink dynamics of a reintroduced lynx population in Central Europe. Biol. Conserv. 2018, 224, 355-365. [CrossRef]

26. Gantchoff, M.G.; Hill, J.E.; Kellner, K.F.; Fowler, N.L.; Petroelje, T.R.; Conlee, L.; Beyer, D.E.; Belant, J.L. Mortality of a large wide-ranging mammal largely caused by anthropogenic activities. Sci. Rep. 2020, 10, 1-11. [CrossRef]

27. Frid, M.; Dill, L. Human-caused disturbance stimuli as a form of predation risk. Conserv. Ecol. 2002, 6, 11. [CrossRef]

28. Beale, C.M.; Monaghan, P. Behavioural responses to human disturbance: A matter of choice? Anim. Behav. 2004, 68, 1065-1069. [CrossRef]

29. Stankowich, T. Ungulate flight responses to human disturbance: A review and meta-analysis. Biol. Conserv. 2008, 141, 2159-2173. [CrossRef]

30. Ripple, W.; Beschta, R. Linking Wolves and Plants: Aldo Leopold on Trophic Cascades. Bioscience 2005, 55, 613-621. [CrossRef]

31. Sinclair, A.R.E.; Krebs, C.J. Complex numerical responses to top-down and bottom-up processes in vertebrate populations. Phil. Trans. R. Soc. Lond. B 2002, 357, 1221-1231. [CrossRef]

32. Bassi, E.; Gazzola, A.; Bongi, P.; Scandura, M.; Apollonio, M. Relative impact of human harvest and wolf predation on two ungulate species in Central Italy. Ecol. Res. 2020, 35, 662-674. [CrossRef] 
33. Wilmers, C.C.; Metz, M.C.; Stahler, D.R.; Kohl, M.T.; Geremia, C.; Smith, D.W. How climate impacts the composition of wolf-killed elk in northern Yellowstone National Park. J. Anim. Ecol. 2020, 89, 1511-1519. [CrossRef] [PubMed]

34. Muhly, T.B.; Hebblewhite, M.; Paton, D.; Pitt, J.A.; Boyce, M.S.; Musiani, M. Humans Strengthen Bottom-Up Effects and Weaken Trophic Cascades in a Terrestrial Food Web. PLoS ONE 2013, 8, e64311. [CrossRef] [PubMed]

35. Hebblewhite, M.; Hurd, T.E.; White, C.A.; Fryxell, J.M.; Nietvelt, C.G.; McKenzie, J.A.; Bayley, S.E.; Paquet, P.C. Human Activity Mediates a Trophic Cascade Caused by Wolves. Ecology 2005, 86, 2135-2144. [CrossRef]

36. Beschta, R.L.; Ripple, W.J. Large predators and trophic cascades in terrestrial ecosystems of the western United States. Biol. Conserv. 2009, 142, 2401-2414. [CrossRef]

37. Laundré, J.W.; Hernández, L.; Ripple, W.J. The Landscape of Fear: Ecological Implications of Being Afraid. Open Ecol. J. 2010, 3 , 1-7. [CrossRef]

38. Ripple, W.J.; Wirsing, A.J.; Wilmers, C.C.; Letnic, M. Widespread mesopredator effects after wolf extirpation. Biol. Conserv. 2013, 160, 70-79. [CrossRef]

39. Krebs, C.J.; Boonstra, R.; Boutin, S. Using experimentation to understand the 10-year snowshoe hare cycle in the boreal forest of North America. J. Anim. Ecol. 2018, 87, 87-100. [CrossRef]

40. Lima, S.L. Nonlethal Effects in the Ecology of Predator-Prey Interactions. Bioscience 1998, 48, 25-34. [CrossRef]

41. Schmitz, O.J.; Hawlena, D.; Trussell, G.C. Predator control of ecosystem nutrient dynamics. Ecol. Lett. 2010, 13, 1199-1209. [CrossRef]

42. Berger, K. Carnivore-Livestock Conflicts: Effects of Subsidized Predator Control and Economic Correlates on the Sheep Industry. Conserv. Biol. 2006, 20, 751-761. [CrossRef] [PubMed]

43. Woodroffe, R.; Redpath, S. When the hunter becomes the hunted. Science 2015, 348, 1312-1314. [CrossRef] [PubMed]

44. Boyce, M.S. Wolves for Yellowstone: Dynamics in time and space. J. Mammal. 2018, 99, 1021-1031. [CrossRef]

45. Creel, S.; Christianson, D. Relationships between direct predation and risk effects. Trends Ecol. Evol. 2008, 23, 194-201. [CrossRef]

46. Wilmers, C.C.; Crabtree, R.L.; Smith, D.W.; Murphy, K.M.; Wayne, M. Trophic facilitation by introduced top predators: Grey wolf subsidies to scavengers in Yellowstone National Park. J. Anim. Ecol. 2003, 72, 909-916. [CrossRef]

47. Ripple, W.J.; Beschta, R.L. Wolves and the Ecology of Fear: Can Predation Risk Structure Ecosystems? Bioscience 2004, 54, 755-766. [CrossRef]

48. Kohl, M.T.; Stahler, D.R.; Metz, M.C.; Forester, J.D.; Kauffman, M.J.; Varley, N.; White, P.J.; Smith, D.W.; MacNulty, D.R. Diel predator activity drives a dynamic landscape of fear. Ecol. Monogr. 2018, 88, 638-652. [CrossRef]

49. Middleton, A.D.; Kauffman, M.J.; Mcwhirter, D.E.; Jimenez, M.D.; Cook, R.C.; Cook, J.G.; Albeke, S.E.; Sawyer, H.; White, P.J. Linking anti-predator behaviour to prey demography reveals limited risk effects of an actively hunting large carnivore. Ecol. Lett. 2013, 16, 1023-1030. [CrossRef] [PubMed]

50. Oates, B.A.; Merkle, J.A.; Kauffman, M.J.; Dewey, S.R.; Jimenez, M.D.; Vartanian, J.M.; Becker, S.A.; Goheen, J.R. Antipredator response diminishes during periods of resource deficit for a large herbivore. Ecology 2019, 100, 1-8. [CrossRef]

51. Peterson, R.O.; Vucetich, J.A.; Bump, J.M.; Smith, D.W. Trophic cascades in a multicausal world: Isle Royale and Yellowstone. Annu. Rev. Ecol. Evol. Syst. 2014, 45, 325-345. [CrossRef]

52. Smith, D.W.; Peterson, R.O.; Houston, D.B. Yellowstone after Wolves. Bioscience 2003, 53, 330-340. [CrossRef]

53. Dalerum, F.; Somers, M.J.; Kunkel, K.E.; Cameron, E.Z. The potential for large carnivores to act as biodiversity surrogates in southern Africa. Biodivers. Conserv. 2008, 17, 2939-2949. [CrossRef]

54. McLaren, B.E.; Peterson, R.O. Wolves, moose, and tree rings on Isle Royale. Science 1994, 266, 1555-1558. [CrossRef] [PubMed]

55. Vucetich, J.A.; Peterson, R.O.; Schaefer, C.C. The effect of prey and predator densities on wolf predation. Ecology 2002, 83, 3003-3013. [CrossRef]

56. Vucetich, J.A.; Peterson, R.O. The influence of top-down, bottom-up and abiotic factors on the moose (Alces alces) population of Isle Royale. Proc. R. Soc. B Biol. Sci. 2004, 271, 183-189. [CrossRef]

57. Hebblewhite, M. Predation by wolves interacts with the North Pacific Oscillation (NPO) on a western North American elk population. J. Anim. Ecol. 2005, 74, 226-233. [CrossRef]

58. Peers, M.J.L.; Majchrzak, Y.N.; Menzies, A.K.; Studd, E.K.; Bastille-Rousseau, G.; Boonstra, R.; Humphries, M.; Jung, T.S.; Kenney, A.J.; Krebs, C.J.; et al. Climate change increases predation risk for a keystone species of the boreal forest. Nat. Clim. Chang. 2020, 10, 1149-1153. [CrossRef]

59. Ripple, W.J.; Beschta, R.L. Linking a cougar decline, trophic cascade, and catastrophic regime shift in Zion National Park. Biol. Conserv. 2006, 133, 397-408. [CrossRef]

60. Callan, R.; Nibbelink, N.P.; Rooney, T.P.; Wiedenhoeft, J.E.; Wydeven, A.P. Recolonizing wolves trigger a trophic cascade in Wisconsin (USA). J. Ecol. 2013, 101, 837-845. [CrossRef]

61. Flagel, D.G.; Belovsky, G.E.; Beyer, D.E. Natural and experimental tests of trophic cascades: Gray wolves and white-tailed deer in a Great Lakes forest. Oecologia 2016, 180, 1183-1194. [CrossRef]

62. Gable, T.D.; Johnson-Bice, S.M.; Homkes, A.T.; Windels, S.K.; Bump, J.K. Outsized effect of predation: Wolves alter wetland creation and recolonization by killing ecosystem engineers. Sci. Adv. 2020, 6, 5439-5452. [CrossRef] [PubMed]

63. Ordiz, A.; Uzal, A.; Milleret, C.; Sanz-Pérez, A.; Zimmermann, B.; Wikenros, C.; Wabakken, P.; Kindberg, J.; Swenson, J.E.; Sand, H. Wolf habitat selection when sympatric or allopatric with brown bears in Scandinavia. Sci. Rep. 2020, 10, 1-11. [CrossRef] [PubMed] 
64. Servheen, C.; Herrero, H.; Peyton, B. Bears: Status Survey and Conservation Action Plan; IUCN/SSC Bear and Polar Bear Specialists Group; IUCN Publications Unit: Cambridge, UK, 1999.

65. Ordiz, A.; Milleret, C.; Uzal, A.; Zimmermann, B.; Wabakken, P.; Wikenros, C.; Sand, H.; Swenson, J.E.; Kindberg, J. Individual variation in predatory behavior, scavenging and seasonal prey availability as potential drivers of coexistence between wolves and bears. Diversity 2020, 12, 356. [CrossRef]

66. Niedziałkowska, M.; Hayward, M.W.; Borowik, T.; Jędrzejewski, W.; Jędrzejewska, B. A meta-analysis of ungulate predation and prey selection by the brown bear Ursus arctos in Eurasia. Mammal Res. 2019, 64, 1-9. [CrossRef]

67. Carlson, S.M.; Hilborn, R.; Hendry, A.P.; Quinn, T.P. Predation by bears drives senescence in natural populations of salmon. PLoS ONE 2007, 2, e1286. [CrossRef]

68. Genovart, M.; Negre, N.; Tavecchia, G.; Bistuer, A.; Parpal, L.; Oro, D. The young, the weak and the sick: Evidence of natural selection by predation. PLoS ONE 2010, 5, e9774. [CrossRef]

69. Wills, B.D.; Landis, D.A. The role of ants in north temperate grasslands: A review. Oecologia 2018, 186, 323-338. [CrossRef]

70. Tosoni, E.; Mei, M.; Ciucci, P. Ants as food for Apennine brown bears. Eur. Zool. J. 2018, 85, 343-349. [CrossRef]

71. Swenson, J.E.; Jansson, A.; Riig, R.; Sandegren, F. Bears and ants: Myrmecophagy by brown bears in central Scandinavia. Can. J. Zool. 1999, 77, 551-561. [CrossRef]

72. Grinath, J.B.; Inouye, B.D.; Underwood, N. Bears benefit plants via a cascade with both antagonistic and mutualistic interactions. Ecol. Lett. 2015, 18, 164-173. [CrossRef] [PubMed]

73. Grinath, J.B. Short-term, low-level nitrogen deposition dampens a trophic cascade between bears and plants. Ecol. Evol. 2018, 8, 11213-11223. [CrossRef]

74. Harrer, L.E.F.; Levi, T. The primacy of bears as seed dispersers in salmon-bearing ecosystems. Ecosphere 2018, 9, e02076. [CrossRef]

75. Shakeri, Y.N.; White, K.S.; Levi, T. Salmon-supported bears, seed dispersal, and extensive resource subsidies to granivores. Ecosphere 2018, 9, e02297. [CrossRef]

76. Steyaert, S.M.J.G.; Hertel, A.G.; Swenson, J.E. Endozoochory by brown bears stimulates germination in bilberry. Wildl. Biol. 2019, 2019, 1-5. [CrossRef]

77. Lalleroni, A.; Quenette, P.Y.; Daufresne, T.; Pellerin, M.; Baltzinger, C. Exploring the potential of brown bear (Ursus arctos arctos) as a long-distance seed disperser: A pilot study in South-Western Europe. Mammalia 2017, 81, 1-9. [CrossRef]

78. Naoe, S.; Tayasu, I.; Sakai, Y.; Masaki, T.; Kobayashi, K.; Nakajima, A.; Sato, Y.; Yamazaki, K.; Kiyokawa, H.; Koike, S. Downhill seed dispersal by temperate mammals: A potential threat to plant escape from global warming. Sci. Rep. 2019, 9, 1-11. [CrossRef] [PubMed]

79. Sarasola, J.H.; Zanón-Martínez, J.I.; Costán, A.S.; Ripple, W.J. Hypercarnivorous apex predator could provide ecosystem services by dispersing seeds. Sci. Rep. 2016, 6, 1-6. [CrossRef]

80. Bump, J.K.; Webster, C.R.; Vucetich, J.A.; Peterson, R.O.; Shields, J.M.; Powers, M.D. Ungulate carcasses perforate ecological filters and create biogeochemical hotspots in forest herbaceous layers allowing trees a competitive advantage. Ecosystems 2009, 12, 996-1007. [CrossRef]

81. DeVault, T.L.; Rhodes, O.E.R., Jr.; Shivik, J.A.; Devault, T.L.; Rhodes, O.E.; Shivik, J.A. Scavenging by vertebrates: Behavioral, ecological, and evolutionary perspectives on an important energy transfer pathway in terrestrial ecosystems. Oikos 2003, 102, 225-234. [CrossRef]

82. Mattisson, J.; Rauset, G.R.; Odden, J.; Andrén, H.; Linnell, J.D.C.; Persson, J. Predation or scavenging? Prey body condition influences decision-making in a facultative predator, the wolverine. Ecosphere 2016, 7, e01407. [CrossRef]

83. Mattisson, J.; Andrén, H.; Persson, J.; Segerström, P. Influence of intraguild interactions on resource use by wolverines and Eurasian lynx. J. Mammal. 2011, 92, 1321-1330. [CrossRef]

84. Ordiz, A.; Milleret, C.; Kindberg, J.; Mansson, J.; Wabakken, P.; Swenson, J.E.; Sand, H. Wolves, people, and brown bears influence the expansion of the recolonizing Wolf population in Scandinavia. Ecosphere 2015, 6, 1-14. [CrossRef]

85. May, R.; Van Dijk, J.; Wabakken, P.; Swenson, J.E.; Linnell, J.D.C.; Odden, J.; Pedersen, H.C.; Andersen, R.; Landa, A. Habitat differentiation within the large-carnivore community of Norway's multiple-use landscapes. J. Appl. Ecol. 2008, 45, $1382-1391$. [CrossRef]

86. Estes, B.J.A.; Carswell, L.P. Costs and benefits of living with predators. Science 2020, 368, 1178-1180. [CrossRef]

87. Frank, L.G.; Woodroffe, R. Behaviour of carnivores in controlled and exploited populations. In Carnivore Conservation; Gittleman, J.L., Wayne, R.K., Macdonald, D.W., Funk, S.M., Eds.; Cambridge University Press: Cambridge, UK, 2001.

88. Bischof, R.; Steyaert, S.M.J.G.; Kindberg, J. Caught in the mesh: Roads and their network-scale impediment to animal movement. Ecography 2017, 40, 1369-1380. [CrossRef]

89. Ordiz, A.; Delibes, M.; Støen, O.-G.; Swenson, J.E. Predators or prey? Spatio-temporal discrimination of human-derived risk by brown bears. Oecologia 2011, 166, 59-67. [CrossRef] [PubMed]

90. Oriol-Cotterill, A.; Valeix, M.; Frank, L.G.; Riginos, C.; Macdonald, D.W. Landscapes of Coexistence for terrestrial carnivores: The ecological consequences of being downgraded from ultimate to penultimate predator by humans. Oikos 2015, 124, 1263-1273. [CrossRef]

91. Macdonald, D.W. Animal behaviour and its role in carnivore conservation: Examples of seven deadly threats. Anim. Behav. 2016, 120, 197-209. [CrossRef] 
92. Persson, J.; Ericsson, G.; Segerström, P. Human caused mortality in the endangered Scandinavian wolverine population. Biol. Conserv. 2009, 142, 325-331. [CrossRef]

93. Liberg, O.; Aronson, A.; Sand, H.; Wabakken, P.; Maartmann, E.; Svensson, L.; Åkesson, M. Monitoring of wolves in Scandinavia. Hystrix 2012, 23, 29-34. [CrossRef]

94. Milleret, C.; Ordiz, A.; Chapron, G.; Andreassen, H.P.; Kindberg, J.; Månsson, J.; Tallian, A.; Wabakken, P.; Wikenros, C.; Zimmermann, B.; et al. Habitat segregation between brown bears and gray wolves in a human-dominated landscape. Ecol. Evol. 2018, 8, 1-17. [CrossRef]

95. Moe, T.F.; Kindberg, J.; Jansson, I.; Swenson, E. Importance of diel behaviour when studying habitat selection: Examples from female Scandinavian brown bears (Ursus arctos). Can. J. Zool. 2007, 525, 518-525. [CrossRef]

96. Martin, J.; Basille, M.; Van Moorter, B.; Kindberg, J.; Allainé, D.; Swenson, J.E. Coping with human disturbance: Spatial and temporal tactics of the brown bear (Ursus arctos). Can. J. Zool. 2010, 88, 875-883. [CrossRef]

97. White, S.; Briers, R.; Bouyer, T.; Odden, J.; Linnell, J. Eurasian lynx natal den site and maternal home-range selection in multi-use landscapes of Norway. J. Zool. 2015, 197, 87-98. [CrossRef]

98. Sahlén, V.; Ordiz, A.; Swenson, J.E.; Støen, O.G. Behavioural differences between single Scandinavian brown bears (Ursus arctos) and females with dependent young when experimentally approached by humans. PLoS ONE 2015, 10, e0121576. [CrossRef]

99. Moen, G.K.; Støen, O.G.; Sahlén, V.; Swenson, J.E. Behaviour of solitary adult Scandinavian brown bears (Ursus arctos) when approached by humans on foot. PLoS ONE 2012, 7, e31699. [CrossRef]

100. Wam, H.K.; Eldegard, K.; Hjeljord, O. From overlooking to concealed: Predator avoidance in an apex carnivore. Eur. J. Wildl. Res. 2012, 58, 1001-1003. [CrossRef]

101. Basille, M.; Herfindal, I.; Santin-janin, H.; Linnell, J.D.C.; Odden, J.; Andersen, R.; Høgda, K.A.; Gaillard, J. What shapes Eurasian lynx distribution in human dominated landscapes: Selecting prey or avoiding people? Ecography 2009, 32, 683-691. [CrossRef]

102. Ordiz, A.; Støen, O.G.; Sæbø, S.; Kindberg, J.; Delibes, M.; Swenson, J.E. Do bears know they are being hunted? Biol. Conserv. 2012, 152, 21-28. [CrossRef]

103. Ordiz, A.; Kindberg, J.; Sæbø, S.; Swenson, J.E.; Støen, O.G. Brown bear circadian behavior reveals human environmental encroachment. Biol. Conserv. 2014, 173, 1-9. [CrossRef]

104. Ordiz, A.; Sæbø, S.; Kindberg, J.; Swenson, J.E.; Støen, O.G. Seasonality and human disturbance alter brown bear activity patterns: Implications for circumpolar carnivore conservation? Anim. Conserv. 2017, 20, 51-60. [CrossRef]

105. Ordiz, A.; Støen, O.G.; Sæbø, S.; Sahlén, V.; Pedersen, B.E.; Kindberg, J.; Swenson, J.E. Lasting behavioural responses of brown bears to experimental encounters with humans. J. Appl. Ecol. 2013, 50, 306-314. [CrossRef]

106. Ordiz, A.; Moen, G.K.; Sæbø, S.; Stenset, N.; Swenson, J.E.; Støen, O.G. Habituation, sensitization, or consistent behavioral responses? Brown bear responses after repeated approaches by humans on foot. Biol. Conserv. 2019, 232, 228-237. [CrossRef]

107. Støen, O.G.; Ordiz, A.; Evans, A.L.; Laske, T.G.; Kindberg, J.; Fröbert, O.; Swenson, J.E.; Arnemo, J.M. Physiological evidence for a human-induced landscape of fear in brown bears (Ursus arctos). Physiol. Behav. 2015, 152, 244-248. [CrossRef]

108. Williams, T.M.; Jørgensen, M.P.; Pagano, A.M.; Bryce, C.M. Hunters versus hunted: New perspectives on the energetic costs of survival at the top of the food chain. Funct. Ecol. 2020, 34, 2015-2029. [CrossRef]

109. Mueller, C.; Herrero, S.; Gibeau, M.L. Distribution of subadult grizzly bears in relation to human development in the Bow River Watershed, Alberta. Ursus 2004, 15, 35-47. [CrossRef]

110. Jedrzejewski, W.; Schmidt, K.; Theuerkauf, J.; Jedrzejewska, B.; Okarma, H. Daily movements and territory use by radio-collared wolves (Canis lupus) in Bialowieza Primeval Forest in Poland. Can. J. Zool. 2001, 79, 1993-2004. [CrossRef]

111. May, R.; Landa, A.; Van Dijk, J.; Linnell, J.D.C.; Andersen, R. Impact of infrastructure on habitat selection of wolverines Gulo gulo. Wildl. Biol. 2006, 12, 285-295. [CrossRef]

112. Davidson, Z.; Valeix, M.; Loveridge, A.J.; Hunt, J.E.; Johnson, P.J.; Madzikanda, H.; Macdonald, D.W. Environmental determinants of habitat and kill site selection in a large carnivore: Scale matters. J. Mammal. 2012, 93, 677-685. [CrossRef]

113. Kortello, A.; Hausleitner, D.; Mowat, G. Mechanisms influencing the winter distribution of wolverine Gulo gulo luscus in the southern Columbia Mountains, Canada. Wildl. Biol. 2019, 2019, 1-13. [CrossRef]

114. Johnson, A.; Vongkhamheng, C.; Hedemark, M.; Saithongdam, T. Effects of human-carnivore conflict on tiger (Panthera tigris) and prey populations in Lao PDR. Anim. Conserv. 2006, 9, 421-430. [CrossRef]

115. Linke, J.; McDermid, G.J.; Fortin, M.J.; Stenhouse, G.B. Relationships between grizzly bears and human disturbances in a rapidly changing multi-use forest landscape. Biol. Conserv. 2013, 166, 54-63. [CrossRef]

116. Gaynor, K.M.; Hojnowski, C.E.; Carter, N.H.; Brashares, J.S. The influence of human disturbance on wildlife nocturnality. Science 2018, 1235, 1232-1235. [CrossRef] [PubMed]

117. Swenson, J.E. Does hunting affect the behavior of brown bears in Eurasia? Ursus 1999, 11, 157-162.

118. Zedrosser, A.; Steyaert, S.M.J.G.; Gossow, H.; Swenson, J.E. Brown bear conservation and the ghost of persecution past. Biol. Conserv. 2011, 144, 2163-2170. [CrossRef]

119. George, S.L.; Crooks, K.R. Recreation and large mammal activity in an urban nature reserve. Biol. Conserv. 2006, 133, 107-117. [CrossRef]

120. Fortin, J.K.; Rode, K.D.; Hilderbrand, G.V.; Wilder, J.; Farley, S.; Jorgensen, C.; Marcot, B.G. Impacts of human recreation on brown bears (Ursus arctos): A review and new management tool. PLoS ONE 2016, 11, e0141983. [CrossRef] [PubMed] 
121. Penteriani, V.; López-Bao, J.V.; Bettega, C.; Dalerum, F.; Delgado, M.d.M.; Jerina, K.; Kojola, I.; Krofel, M.; Ordiz, A. Consequences of brown bear viewing tourism: A review. Biol. Conserv. 2017, 206, 169-180. [CrossRef]

122. Anton, C.B.; Smith, D.W.; Suraci, J.P.; Stahler, D.R.; Duane, T.P.; Wilmers, C.C. Gray wolf habitat use in response to visitor activity along roadways in Yellowstone National Park. Ecosphere 2020, 11, e03164. [CrossRef]

123. Darimont, C.T.; Fox, C.H.; Bryan, H.M.; Reimchen, T.E. The unique ecology of human predators. Science 2015, 349, 858-860. [CrossRef]

124. Crooks, K.R.; Soulé, M.E. Mesopredator release and avifaunal extinctions in a fragmented system. Nature 1999, 400, 563-566. [CrossRef]

125. Ritchie, E.G.; Johnson, C. Predator interactions, mesopredator release and biodiversity conservation. Ecol. Lett. 2009, 12, 982-998. [CrossRef]

126. Prugh, L.R.; Stoner, C.J.; Epps, C.W.; Bean, W.T.; Ripple, W.J. The Rise of the Mesopredator. Bioscience 2009, 59, 779-791. [CrossRef]

127. Elmhagen, B.; Ludwig, G.; Rushton, S.P.; Helle, P.; Lindén, H. Top predators, mesopredators and their prey: Interference ecosystems along bioclimatic productivity gradients. J. Anim. Ecol. 2010, 79, 785-794. [CrossRef]

128. Berger, J. Fear, human shields and the redistribution of prey and predators in protected areas. Biol. Lett. 2007, 3, 620-623. [CrossRef] [PubMed]

129. Muhly, T.B.; Semeniuk, C.; Massolo, A.; Hickman, L.; Musiani, M. Human activity helps prey win the predator-prey space race. PLOS ONE 2011, 6, e17050. [CrossRef]

130. Rogala, J.K.; Hebblewhite, M.; Whittington, J.; White, C.A.; Coleshill, J.; Musiani, M. Human Activity Differentially Redistributes Large Mammals in the Canadian Rockies National Parks. Ecol. Soc. 2011, 16, 16. [CrossRef]

131. Wilson, M.W.; Ridlon, A.D.; Gaynor, K.M.; Gaines, S.D.; Stier, A.C.; Halpern, B.S. Ecological impacts of human-induced animal behaviour change. Ecol. Lett. 2020, 23, 1522-1536. [CrossRef]

132. Hoeks, S.; Huijbregts, M.A.J.; Busana, M.; Harfoot, M.B.J.; Svenning, J.C.; Santini, L. Mechanistic insights into the role of large carnivores for ecosystem structure and functioning. Ecography 2020, 43, 1752-1763. [CrossRef]

133. Frey, S.; Volpe, J.P.; Heim, N.A.; Paczkowski, J.; Fisher, J.T. Move to nocturnality not a universal trend in carnivore species on disturbed landscapes. Oikos 2020, 129, 1128-1140. [CrossRef]

134. Smith, J.A.; Wang, Y.; Wilmers, C.C. Top carnivores increase their kill rates on prey as a response to human-induced fear. Proc. R. Soc. B Biol. Sci. 2015, 282, 20142711. [CrossRef]

135. Smith, J.A.; Suraci, J.P.; Clinchy, M.; Crawford, A.; Roberts, D.; Zanette, L.Y.; Wilmers, C.C. Fear of the human 'super predator' reduces feeding time in large carnivores. Proc. R. Soc. B Biol. Sci. 2017, 284, 20170433. [CrossRef]

136. Stewart, F.E.C.; Heim, N.A.; Clevenger, A.P.; Paczkowski, J.; Volpe, J.P.; Fisher, J.T. Wolverine behavior varies spatially with anthropogenic footprint: Implications for conservation and inferences about declines. Ecol. Evol. 2016, 6, 1493-1503. [CrossRef]

137. Moen, G.K. Human-Mediated Effects on Brown Bear Behavior and Potential Cascading Effects. PhD Thesis, Norwegian University of Life Sciences, Ås, Norway, 2018.

138. Levi, T.; Kilpatrick, A.M.; Mangel, M.; Wilmers, C.C. Deer, predators, and the emergence of Lyme disease. Proc. Natl. Acad. Sci. USA 2012, 109, 10942-10947. [CrossRef]

139. Blome, S.; Franzke, K.; Beer, M. African swine fever-A review of current knowledge. Virus Res. 2020, 287, 198099. [CrossRef] [PubMed]

140. Vetter, S.G.; Puskas, Z.; Bieber, C.; Ruf, T. How climate change and wildlife management affect population structure in wild boars. Sci. Rep. 2020, 10, 7298. [CrossRef]

141. Nores, C.; Llaneza, L.; Álvarez, M.Á. Wild boar Sus scrofa mortality by hunting and wolf Canis lupus predation: An example in northern Spain. Wildl. Biol. 2008, 14, 44-51. [CrossRef]

142. Ciucci, P.; Mancinelli, S.; Boitani, L.; Gallo, O.; Grottoli, L. Anthropogenic food subsidies hinder the ecological role of wolves: Insights for conservation of apex predators in human-modified landscapes. Glob. Ecol. Conserv. 2020, 21, e00841. [CrossRef]

143. Novaro, A.; Walker, S. Human-Induced Changes in the Effect of Top Carnivores on Biodiversity in the Patagonian Steppe. In Large Carnivores and the Conservation of Biodiversity; Ray, J.C., Redford, K.H., Steneck, R., Berger, J., Eds.; Island Press: Washington, DC, USA, 2005; pp. 268-288.

144. Wallach, A.D.; Neill, A.J.O. Threatened species indicate hot-spots of top-down regulation. Anim. Biodivers. Conserv. 2009, 32, 127-133.

145. Serrouya, R.; McLellan, B.N.; van Oort, H.; Mowat, G.; Boutin, S. Experimental moose reduction lowers wolf density and stops decline of endangered caribou. Peer] 2017, 5, e3736. [CrossRef] [PubMed]

146. Newsome, T.M.; Dellinger, J.A.; Pavey, C.R.; Ripple, W.J.; Shores, C.R.; Wirsing, A.J.; Dickman, C.R. The ecological effects of providing resource subsidies to predators. Glob. Ecol. Biogeogr. 2015, 24, 1-11. [CrossRef]

147. Salvatori, V.; Godinho, R.; Braschi, C.; Boitani, L.; Ciucci, P. High levels of recent wolf $\times$ dog introgressive hybridization in agricultural landscapes of central Italy. Eur. J. Wildl. Res. 2019, 65, 73. [CrossRef]

148. Donfrancesco, V.; Ciucci, P.; Salvatori, V.; Benson, D.; Andersen, L.W.; Bassi, E.; Blanco, J.C.; Boitani, L.; Caniglia, R.; Canu, A.; et al. Unravelling the scientific debate on how to address wolf-dog hybridization in Europe. Front. Ecol. Evol. 2019, 7, 175. [CrossRef]

149. Kuijper, D.P.J.; Sahlén, E.; Elmhagen, B.; Chamaillé-Jammes, S.; Sand, H.; Lone, K.; Cromsigt, J.P.G.M. Paws without claws? Ecological effects of large carnivores in anthropogenic landscapes. Proc. R. Soc. B Biol. Sci. 2016, 283, 20161625. [CrossRef] [PubMed] 
150. Sand, H.; Wikenros, C.; Wabakken, P.; Liberg, O. Cross-continental differences in patterns of predation: Will naive moose in Scandinavia ever learn? Proc. R. Soc. B Biol. Sci. 2006, 273, 1421-1427. [CrossRef] [PubMed]

151. Pusenius, J.; Kukko, T.; Melin, M.; Laaksonen, S.; Kojola, I. Wolf predation risk and moose movement in eastern Finland. Wildl. Biol. 2020, 2020. [CrossRef]

152. Van Dijk, J.; Gustavsen, L.; Mysterud, A.; May, R.; Flagstad, Ø.; Brøseth, H.; Andersen, R.; Andersen, R.; Steen, H.; Landa, A. Diet shift of a facultative scavenger, the wolverine, following recolonization of wolves. J. Anim. Ecol. 2008, 77, 1183-1190. [CrossRef]

153. Helldin, J.O.; Liberg, O.; Glöersen, G. Lynx (Lynx lynx) killing red foxes (Vulpes vulpes) in boreal Sweden-frequency and population effects. J. Zool. 2006, 270, 657-663. [CrossRef]

154. Elmhagen, B.; Rushton, S.P. Trophic control of mesopredators in terrestrial ecosystems: Top-down or bottom-up? Ecol. Lett. 2007, 10, 197-206. [CrossRef]

155. Jedrzejewska, B.; Jedrzejewski, W. Large Carnivores and Ungulates in European Temperate Forest Ecosystems: Bottom-Up and Top-Down Control. In Large Carnivores and the Conservation of Biodiversity; Ray, J.C., Redford, K.H., Steneck, R., Berger, J., Eds.; Island Press: Washington, DC, USA, 2005; pp. 230-246.

156. Palomares, F.; Gaona, P.; Ferreras, P.; Delibes, M. Positive Effects on Game Species of Top Predators by Controlling Smaller Predator Populations: An Example with Lynx, Mongooses, and Rabbits. Conserv. Biol. 1995, 9, 295-305. [CrossRef]

157. Sahlén, E.; Noell, S.; Deperno, C.S.; Kindberg, J.; Spong, G.; Cromsigt, J.P.G.M. Phantoms of the forest: Legacy risk effects of a regionally extinct large carnivore. Ecol. Evol. 2016, 6, 791-799. [CrossRef] [PubMed]

158. Sinclair, A.R.E.; Krebs, C.J.; Fryxell, J.M.; Turkington, R.; Boutin, S.; Boonstra, R.; Seccombe-Hett, P.; Lundberg, P.; Oksanen, L. Testing Hypotheses of Trophic Level Interactions: A Boreal Forest Ecosystem. Oikos 2000, 89, 313-328. [CrossRef]

159. Lozano, J.; Olszańska, A.; Morales-Reyes, Z.; Castro, A.A.; Malo, A.F.; Moleón, M.; Sánchez-Zapata, J.A.; Cortés-Avizanda, A.; von Wehrden, H.; Dorresteijn, I.; et al. Human-carnivore relations: A systematic review. Biol. Conserv. 2019, 237, 480-492. [CrossRef]

160. Smith, B.P.; Appleby, R.G.; Jordan, N.R. Co-existing with dingoes: Challenges and solutions to implementing non-lethal management. Aust. Zool. 2020. [CrossRef]

161. Creel, S.; Spong, G.; Becker, M.; Simukonda, C.; Norman, A.; Schiffthaler, B.; Chifunte, C. Carnivores, competition and genetic connectivity in the Anthropocene. Sci. Rep. 2019, 9, 1-8. [CrossRef] [PubMed]

162. Li, S.; McShea, W.J.; Wang, D.; Gu, X.; Zhang, X.; Zhang, L.; Shen, X. Retreat of large carnivores across the giant panda distribution range. Nat. Ecol. Evol. 2020, 4, 1327-1331. [CrossRef]

163. Gill, J.A. Approaches to measuring the effects of human disturbance on birds. Ibis 2007, 149, 9-14. [CrossRef]

164. Tarlow, E.M.; Blumstein, D.T. Evaluating methods to quantify anthropogenic stressors on wild animals. Appl. Anim. Behav. Sci. 2007, 102, 429-451. [CrossRef]

165. Penteriani, V.; Delgado, M.D.M.; Krofel, M.; Jerina, K.; Ordiz, A.; Dalerum, F.; Zarzo-Arias, A.; Bombieri, G. Evolutionary and ecological traps for brown bears Ursus arctos in human-modified landscapes. Mamm. Rev. 2018, 48, 180-193. [CrossRef]

166. Morales-González, A.; Ruiz-Villar, H.; Ordiz, A.; Penteriani, V. Large carnivores living alongside humans: Brown bears in human-modified landscapes. Glob. Ecol. Conserv. 2020, 22, 1-13. [CrossRef]

167. Lamb, C.T.; Ford, A.T.; McLellan, B.N.; Proctor, M.F.; Mowat, G.; Ciarniello, L.; Nielsen, S.E.; Boutin, S. The ecology of humancarnivore coexistence. Proc. Natl. Acad. Sci. USA 2020, 117, 17876-17883. [CrossRef] [PubMed]

168. Bergstrom, B.J.; Vignieri, S.; Sheffield, S.R.; Sechrest, W.E.S.; Carlson, A.A. The Northern Rocky Mountain Gray Wolf Is Not Yet Recovered. BioScience 2009, 59, 991-999. [CrossRef]

169. Redpath, S.M.; Young, J.; Evely, A.; Adams, W.M.; Sutherland, W.J.; Whitehouse, A.; Amar, A.; Lambert, R.A.; Linnell, J.D.C.; Watt, A.; et al. Understanding and managing conservation conflicts. Trends Ecol. Evol. 2013, 28, 100-109. [CrossRef] [PubMed]

170. Stier, A.C.; Samhouri, J.F.; Novak, M.; Marshall, K.N.; Ward, E.J.; Holt, R.D.; Levin, P.S. Ecosystem context and historical contingency in apex predator recoveries. Sci. Adv. 2016, 2, 1-15. [CrossRef] [PubMed]

171. Perino, A.; Pereira, H.M.; Navarro, L.M.; Fernández, N.; Bullock, J.M.; Ceauşu, S.; Cortés-Avizanda, A.; Van Klink, R.; Kuemmerle, T.; Lomba, A.; et al. Rewilding complex ecosystems. Science 2019, 364, eaav5570. [CrossRef]

172. Landry, J.-M.; Borelli, J.-L.; Drouilly, M. Interactions between livestock guarding dogs and wolves in the southern French Alps. J. Vertebr. Biol. 2020, 69, 20078. [CrossRef]

173. Enserink, M.; Vogel, G. The Carnivore Comeback. Science 2006, 314, 746-749. [CrossRef] [PubMed]

174. Gilroy, J.J.; Ordiz, A.; Bischof, R. Carnivore coexistence: Value the wilderness. Science 2015, 347, 382. [CrossRef]

175. Nellemann, C.; Støen, O.G.; Kindberg, J.; Swenson, J.E.; Vistnes, I.; Ericsson, G.; Katajisto, J.; Kaltenborn, B.P.; Martin, J.; Ordiz, A. Terrain use by an expanding brown bear population in relation to age, recreational resorts and human settlements. Biol. Conserv. 2007, 138, 157-165. [CrossRef]

176. Ogada, M.O.; Woodroffe, R.; Oguge, N.O.; Frank, L.G. Limiting Depredation by African Carnivores: The Role of Livestock Husbandry. Conserv. Biol. 2003, 17, 1521-1530. [CrossRef]

177. Persson, J.; Rauset, G.R.; Chapron, G. Paying for an endangered predator leads to population recovery. Conserv. Lett. 2015, 8 , 345-350. [CrossRef]

178. Naha, D.; Dash, S.K.; Chettri, A.; Chaudhary, P.; Sonker, G.; Heurich, M.; Rawat, G.S.; Sathyakumar, S. Landscape predictors of human-leopard conflicts within multi-use areas of the Himalayan region. Sci. Rep. 2020, 10, 1-13. [CrossRef] [PubMed]

179. Maxwell, S.L.; Cazalis, V.; Dudley, N.; Hoffmann, M.; Rodrigues, A.S.L.; Stolton, S.; Visconti, P.; Woodley, S.; Kingston, N.; Lewis, E.; et al. Area-based conservation in the twenty-first century. Nature 2020, 586, 217-227. [CrossRef] [PubMed] 
180. Rio-Maior, H.; Nakamura, M.; Álvares, F.; Beja, P. Designing the landscape of coexistence: Integrating risk avoidance, habitat selection and functional connectivity to inform large carnivore conservation. Biol. Conserv. 2019, 235, 178-188. [CrossRef]

181. Ladle, A.; Avgar, T.; Wheatley, M.; Stenhouse, G.B.; Nielsen, S.E.; Boyce, M.S. Grizzly bear response to spatio-temporal variability in human recreational activity. J. Appl. Ecol. 2019, 56, 375-386. [CrossRef]

182. Tolvanen, A.; Kangas, K. Tourism, biodiversity and protected areas-Review from northern Fennoscandia. J. Environ. Manage 2016, 169, 58-66. [CrossRef]

183. Heinemeyer, K.; Squires, J.; Hebblewhite, M.; O’Keefe, J.J.; Holbrook, J.D.; Copeland, J. Wolverines in winter: Indirect habitat loss and functional responses to backcountry recreation. Ecosphere 2019, 10, e02611. [CrossRef]

184. Van Eeden, L.M.; Crowther, M.S.; Dickman, C.R.; Macdonald, D.W.; Ripple, W.J.; Ritchie, E.G.; Newsome, T.M. Managing conflict between large carnivores and livestock. Conserv. Biol. 2018, 32, 26-34. [CrossRef]

185. Stone, S.A.; Breck, S.W.; Timberlake, J.; Haswell, P.M.; Najera, F.; Bean, B.S.; Thornhill, D.J. Adaptive use of nonlethal strategies for minimizing wolf-sheep conflict in Idaho. J. Mammal. 2017, 98, 33-44. [CrossRef]

186. Naves, J.; Ordiz, A.; Fernández-Gil, A.; Penteriani, V.; del Mar Delgado, M.; López-Bao, J.V.; Revilla, E.; Delibes, M. Patterns of brown bear damages on apiaries and management recommendations in the Cantabrian Mountains, Spain. PLoS ONE 2018, 13, e0206733. [CrossRef]

187. Khorozyan, I.; Waltert, M. Variation and conservation implications of the effectiveness of anti-bear interventions. Sci. Rep. 2020, 10, 15341. [CrossRef] [PubMed]

188. Van Eeden, L.M.; Eklund, A.; Miller, J.R.B.; López-Bao, J.V.; Chapron, G.; Cejtin, M.R.; Crowther, M.S.; Dickman, C.R.; Frank, J.; Krofel, M.; et al. Carnivore conservation needs evidence-based livestock protection. PLoS Biol. 2018, 16, 1-8. [CrossRef] [PubMed]

189. Recio, M.R.; Sand, H.; Virgós, E. Promoting grazing or rewilding initiatives against rural exodus? The return of the wolf and other large carnivores must be considered. Environ. Conserv. 2020, 47, 269-276. [CrossRef]

190. Treves, A. Hunting for large carnivore conservation. J. Appl. Ecol. 2009, 46, 1350-1356. [CrossRef]

191. Bischof, R.; Bonenfant, C.; Rivrud, I.M.; Zedrosser, A.; Friebe, A.; Coulson, T.; Mysterud, A.; Swenson, J.E. Regulated hunting re-shapes the life history of brown bears. Nat. Ecol. Evol. 2018, 2, 116-123. [CrossRef] [PubMed]

192. Wallach, A.D.; Ritchie, E.G.; Read, J.; Neill, A.J.O. More than mere numbers: The impact of lethal control on the social stability of a top-order predator. PLoS ONE 2009, 4, e6861. [CrossRef] [PubMed]

193. Wolf, C.; Ripple, W.J. Range contractions of the world's large carnivores. R. Soc. Open Sci. 2017, 4, 170052. [CrossRef] [PubMed]

194. Ordiz, A.; Krofel, M.; Milleret, C.; Seryodkin, I.; Tallian, A.; Støen, O.-G.; Sivertsen, T.; Kindberg, J.; Wabakken, P.; Sand, H.; et al. Interspecific Interactions between Brown Bears, Ungulates, and Other Large Carnivores. In Bears of the World: Ecology, Conservation and Management; Penteriani, V., Melletti, M., Eds.; Cambridge University Press: Cambridge, UK, 2020; pp. 36-44.

195. Laurance, W.F.; Koster, H.; Grooten, M.; Anderson, A.B.; Zuidema, P.A.; Zwick, S.; Zagt, R.J.; Lynam, A.J.; Linkie, M.; Anten, N.P.R. Making conservation research more relevant for conservation practitioners. Biol. Conserv. 2012, 153, 164-168. [CrossRef]

196. Knight, A.T.; Cowling, R.M.; Rouget, M.; Balmford, A.; Lombard, A.T.; Campbell, B.M. Knowing but not doing: Selecting priority conservation areas and the research-implementation gap. Conserv. Biol. 2008, 22, 610-617. [CrossRef]

197. Whittaker, D.; Knight, R.L. Understanding wildlife responses to humans. Wildl. Soc. Bull. 1998, 26, 312-317.

198. Grossmann, C.M.; Patkó, L.; Ortseifen, D.; Kimmig, E.; Cattoen, E.M.; Schraml, U. Human-Large Carnivores Co-existence in Europe-A Comparative Stakeholder Network Analysis. Front. Ecol. Evol. 2020, 8, 1-18. [CrossRef]

199. Jonzén, N.; Sand, H.; Wabakken, P.; Swenson, J.E.; Kindberg, J.; Liberg, O.; Chapron, G. Sharing the bounty-Adjusting harvest to predator return in the Scandinavian human-wolf-bear-moose system. Ecol. Modell. 2013, 265, 140-148. [CrossRef] 